\title{
Management of Popillia japonica in container-grown nursery stock in Italy
}

\author{
Nicola Mori · Giacomo Santoiemma (D) Itamar Glazer • Gianni Gilioli • \\ Mariangela Ciampitti $\cdot$ Beniamino Cavagna $\cdot$ Andrea Battisti
}

Received: 27 April 2021 / Accepted: 13 July 2021 / Published online: 27 July 2021

(C) Springer Nature B.V. 2021

\begin{abstract}
The Japanese beetle Popillia japonica is an invasive alien species recently introduced and established in Northern Italy. Adult beetles are very polyphagous and feed on vines, fruit trees, forest trees, crops, vegetables, ornamental and wild plant species. Eggs are usually laid by females in moist grassland in the summer, singly or in small clusters. Larvae feed on roots and may be transported in soil of plants for planting grown in containers. Restrictions on movement of plants grown in containers from infested to non-infested areas imposed by phytosanitary regulations have a significant economic impact on the nursery industry. An innovative approach was
\end{abstract}

\section{N. Mori}

Department of Biotechnology, University of Verona,

Strada Le Grazie 15, 37134 Verona, Italy

G. Santoiemma $(\bowtie) \cdot$ A. Battisti

DAFNAE, University of Padova, Viale dell'Università 16,

35020 Padova, Legnaro, Italy

e-mail: giacomo.santoiemma@unipd.it

\section{Glazer}

Department Entomology \& Nematology, Agricultural Research Organization, 68 Hamacabim Rd, P.O.

Box 15159, 7528809 Rishon Le Zion, Israel

G. Gilioli

DICATAM, University of Brescia, Via Branze 43,

25123 Brescia, Italy

M. Ciampitti · B. Cavagna

Lombardy Region, Plant Protection Service, Piazza Città

di Lombardia 1, 20124 Milano, Italy used to exclude beetle oviposition by weed mulching available for container-grown nursery stocks, and by testing larval survival to the application of chemical (cypermethrin) and organic (Heterorhabditis bacteriophora and Metarhizium brunneum) commercial pesticides registered for European nurseries. The high effectiveness of the method makes it a suitable component of a systems approach strategy for pest risk management, in order to achieve a safe production and trade of nursery plant material in areas infested by the Japanese beetle.

Keywords Japanese beetle - Quarantine · Mulching $\cdot$ Scarabaeidae $\cdot$ Systems approach

\section{Introduction}

The Japanese beetle, Popillia japonica Newman (Coleoptera: Scarabaeidae), is native to Japan (Fleming, 1972). In the early $20^{\text {th }}$ century, Japanese beetle established in North America in the Atlantic coast, and in 1977 it was recorded in the Russian island of Kunashir, which sits less than $30 \mathrm{~km}$ to the east of Northern Japan (EPPO, 2016). In Europe, $P$. japonica was accidentally introduced into the Azores (Terceira Island) in the early 1970s (Martins \& Simoes, 1988) and it was recently reported in the Italian regions of Lombardy and Piedmont (EPPO, 2014; Pavesi, 2014). In Italy, the insect is currently spreading from the initial area of establishment to the neighbouring areas 
(more than 15,000 $\mathrm{km}^{2}$ ) feeding on vines, fruit trees, forest trees, crops, vegetables, ornamental and wild plant species (Regione Lombardia, 2020). The pest is listed among the priority quarantine organisms of delegated regulation (European Union (EU) 2019/1702) (EFSA PLH Panel, 2018; EPPO, 2021).

Popillia japonica is a significant pest of nursery plants as the adults feed on more than 300 species of trees, shrubs and herbaceous plant species (Fleming, 1972). There are three instars that develop in the soil, feeding on roots of grasses and weeds, but larvae may also consume the young roots of woody ornamental plants (Smitley, 1996). In Europe, the movement of host plants and commodities that might provide a pathway for $P$. japonica is presently regulated by the Annex VII and VIII of the Commission Implementing Regulation (EU 2019/2072) of 28 November 2019, while in North America, the movement of the adult stage by aircraft is regulated by a federal quarantine and the larval stage by the U.S. Domestic Japanese Beetle Harmonization Plan (DJHP) (National Plant Board, 2019).

In the U.S., nursery stock originating from infested areas are managed according to the DJHP. For container-grown nursery stock, accreditation consists of growing plants in containers free of weeds, located on a ground barrier and using approved growing media (Smitley, 1994). Preplant media incorporation of bifenthrin, chlorpyrifos, fensulfathian, isofenphos and tefluthrin formulation provided complete control of Japanese beetle larvae (Ladd \& Lawrence, 1986; Nielsen \& Cowles, 1998). In addition, imidacloprid drenched immediately after planting (Nielsen \& Cowles, 1998) or container immersion with bifenthrin or chlorpyrifos (Oliver et al., 2017) prevented the establishment of the beetle.

Among the effective larval insecticides reported in literature or recommended by DJHP (bifenthrin, chlorpyrifos, cyfluthrin, imidacloprid, thiamethoxam) (National Plant Board, 2019), only imidacloprid for plants grown in permanent greenhouses is allowed in nurseries in European countries. Hence, there is an urgent need to provide solutions for the management of the Japanese beetle in nurseries located in infested areas, which represent a large fraction of the nursery business in Northern Italy. An innovative approach was used to prevent beetle oviposition by testing weed mulching in container-grown nursery stock, either alone or in combination with chemical and organic commercial pesticides registered for European nurseries.

\section{Materials and methods}

Physical barriers to oviposition

The experiment was performed in a nursery located in the infested area (Varese: $45^{\circ} 47^{\prime} \mathrm{N}, 8^{\circ} 45^{\prime} \mathrm{E}$ ). Similar to other $P$. japonica studies with container nursery plants (Oliver et al., 2017), plants were grown in 11.7 L black plastic containers $(37 \mathrm{~cm}$ diameter top and $35 \mathrm{~cm}$ height). Three commercial weed mulching products for container-grown nursery stock were used to determine the penetration capacity of female beetles based on an evaluation of subsequent oviposition in the underlying container substrate, including: coconut fibre mulching discs (two densities: 200 and 400 $\mathrm{g} / \mathrm{cm}^{2}$, producer: Stocker ${ }^{\circledR}$ Lana Bolzano Italy), jute fabric (density: $250 \mathrm{~g} / \mathrm{m}^{2}$, mesh approximately $2 \times 2$ mm, producer: Stocker ${ }^{\circledR}$ Lana Bolzano Italy), wood chips (5 cm layer, chip size: $25-40 \mathrm{~mm}$, producer: Geolia $^{\circledR}$ Morangis France). In June 2020, one-year old grapevine plants (Cultivar Chardonnay grafted on SO4) about $0.5 \mathrm{~m}$ high were transplanted into the containers using peat potting soil (VIV V10-22 Vigor Plant ${ }^{\circledR}$ Fombio Lodi Italy, $80 \%$ Irish and Baltic peats and $20 \%$ sand with a manufacturer reported bulk density of $150 \mathrm{~kg} / \mathrm{m}^{3}, \mathrm{pH} 6.0$ ). A $10 \mathrm{~cm}^{2}$ grass (Lolium perenne L.) sod was put close to the vine to allow oviposition and support larval feeding. A plastic wire net (mesh $2 \times 2 \mathrm{~cm}$ ) was fixed to the container upper edge surrounding the vine stem, to serve as mulching holder. The mulching was put over the net and firmly closed around the vine stem. A cylinder of plastic wire net $0.6 \mathrm{~m}$ high (mesh $1 \mathrm{x} 1 \mathrm{~cm}$ ) was put vertically above the container edge to contain the vine plant; it was then covered with an insect-proof net (mesh $1 \mathrm{x} 1$ $\mathrm{mm}$ ), with an opening in the upper end to introduce the beetles. Each mulching type was replicated four times, and four caged plants without mulching were used as a control. On the 20 July 2020, mating pairs of $P$. japonica adults were collected in a willow nursery (Mornago, Varese: $45^{\circ} 43^{\prime} \mathrm{N}, 8^{\circ} 43^{\prime} \mathrm{E}$ ) and 10 pairs of adult insects (10 females and 10 males) were introduced in each container. The containers were kept under an anti-hail protective net and watered daily according to the nursery standard for the entire 
duration of the experiment. In addition, they were isolated from the soil by a plastic barrier. On the 25 August 2020, the containers were inspected to assess the number of adult beetles, the defoliation level and the number of larvae in the soil; all variables were visually assessed, soil particles were manually separated from the roots and first-instars were identified with a magnifier.

Larval control by preplant media insecticide incorporation trial

Three commercial products registered for use in the nursery industry (EU Pesticide Database, 2020) were evaluated for their effectiveness in killing larvae. Five litre black plastic containers $(24 \mathrm{~cm}$ diameter top and $23 \mathrm{~cm}$ height) were filled with peat potting soil (see previous paragraph) up to $5 \mathrm{~cm}$ from the edge. The soil of the treated containers was mixed manually for approximately 10 minutes with the following products: cypermethrin (Columbo ${ }^{\circledR} 0.8 \mathrm{MG}$, concentration $0.8 \%$, microgranules formulation, corresponding to a field rate of $12 \mathrm{~g} / \mathrm{m}^{3}$, manufacturer: Dow AgroSciences Italy), Metarhizium anisopliae var. anisopliae Sorokin (now taxonomically referred as Metarhizium brunneum Petch) fungus strain F52 (Met $52 \mathrm{G}^{\circledR}$, concentration $2 \%$, granules formulation, corresponding to a field rate of $500 \mathrm{~g} / \mathrm{m}^{3}$, manufacturer: Novozymes France), and Heterorhabditis bacteriophora Poinar nematode (Nematop ${ }^{\circledR}$, powder formulation, corresponding to a field rate of $10^{6}$ infective juveniles $/ \mathrm{m}^{3}$, manufacturer e-nema Germany, commercialised by Biogard, Italy). According to Ladd \& Lawrence (1986) and Oliver et al. (2016), five thirdinstars were used in each container. They were collected on the 18 September 2020 from a hay meadow in Turbigo, Milano (45 $52^{\prime} \mathrm{N}, 08^{\circ} 72^{\prime} \mathrm{E}$ ) and held for at least $24 \mathrm{~h}$ before use, to ensure they were vital and that no mechanical injuries had occurred during collection (Oliver et al., 2016). Each larva was introduced into the containers via $2 \mathrm{~cm}$ deep openings on the surface of the medium and allowed to enter the substrate without further assistance. Third instars were used in the tests since they were readily available and less susceptible than earlier instars to injury from handling and changes in their environment. Elimination of third instar might also support elimination of the earlier instars since they are far more susceptible to some insecticides than the third instar (Fleming, 1972). Each treatment and control were replicated four times and the containers were maintained outdoor in the site where the larvae were collected. On the 3 October 2020 the containers were inspected, and the number of live and dead larvae was assessed.

\section{Statistical analysis}

To evaluate the effectiveness of the mulching type in reducing oviposition, a negative binomial regression model using a log link-function was built and validated. The response variable was the number of first instars found in each container. The categorical explanatory variable (five levels) was the mulching type. To evaluate the effectiveness of the commercial control agents against the third instars, a binomial regression model using a logit link-function was built and validated. The response variable was the mortality rate of larvae (i.e., the ratio between the number of dead larvae and the total number of larvae) in each container. The categorical explanatory variable (four levels) was the treatment. Pairwise multiple comparisons were performed using Tukey's post-hoc tests. All the analyses were performed in R (R Core Team, 2020).

\section{Results}

None of the tested methods provided total suppression of the Japanese beetle in the container-grown nursery stock, either as ovipositing females or third instars in the soil. Among the weed mulching types tested, the coconut mulching was able to reduce the oviposition success when compared to the control and the other types $\left(\chi_{4}^{2}=35.710, p<0.001\right.$; Fig. 1 and Table 1). Thicker coconut mulching (400 g/m $\left.\mathrm{m}^{2}\right)$ yielded a lower number of larvae compared to the less thick $\left(200 \mathrm{~g} / \mathrm{m}^{2}\right)$ but differences were not significant. At the time of the check (25 August 2020), all adults were dead and were retrieved in the cages, either as fully formed (at least 16 adults per container) or damaged. The defoliation of the grapevine plants was almost complete, varying from $75 \%$ to $95 \%$.

Treatments performed with the insecticide cypermethrin and the nematode $H$. bacteriophora 
significantly increased the mortality of the third instars compared to control, while the fungus $M$. brunneum provided intermediate results $\left(\chi_{3}^{2}=\right.$ 14.938, $p=0.002$; Fig. 2 and Table 2).

\section{Discussion}

Potential dispersal of $P$. japonica is of great concern considering that this quarantine pest can be artificially
Fig. 1 Average number of Popillia japonica first instars found in the soil of containers treated with different weed mulching products. Different letters indicate significant differences among weed mulching products in a pairwise comparison $(p<0.05)$ from the negative binomial regression model. Bars indicate the standard error

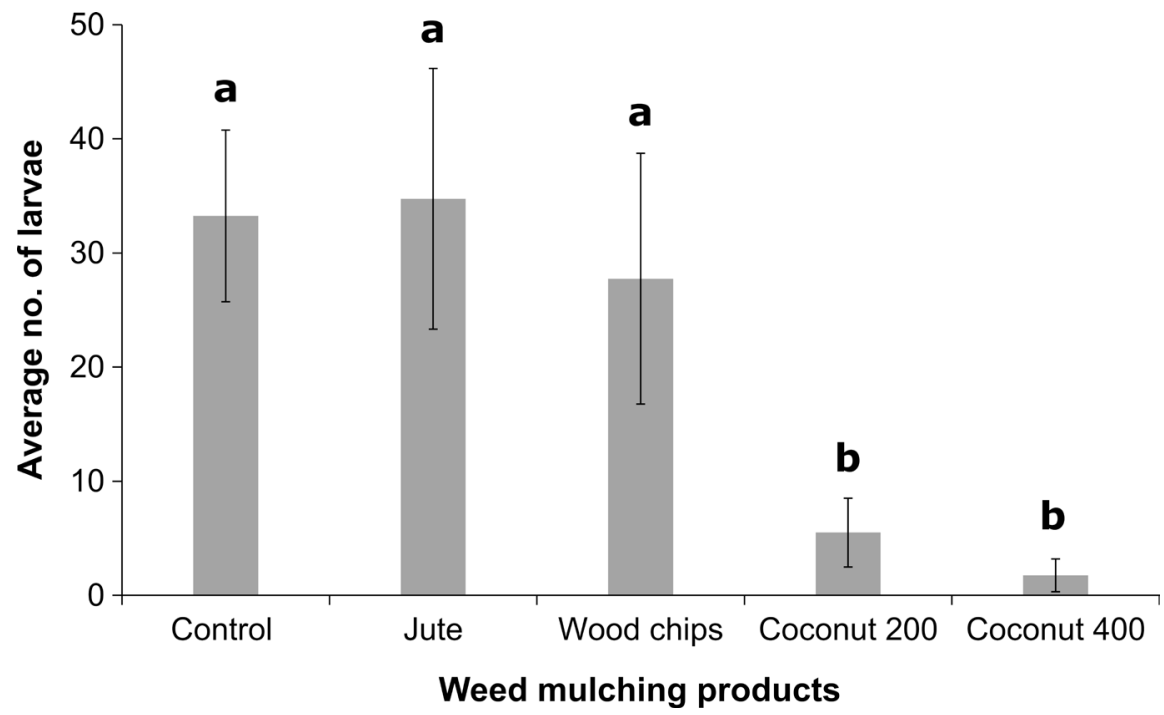

Table 1 Number of first instar larvae of Popillia japonica found in the soil of containers treated with different weed mulching products

Fig. 2 Average death rate of Popillia japonica third instars treated with different insecticides. Different letters indicate significant differences among treatments in a pairwise comparison ( $p$ $<0.05$ ) from the binomial regression model. Bars indicate the standard error

\begin{tabular}{llllll}
\hline Replicate & Control & Jute & Wood chips & Coconut 200 & Coconut 400 \\
\hline 1 & 31 & 61 & 12 & 14 & 1 \\
2 & 14 & 44 & 60 & 3 & 6 \\
3 & 38 & 26 & 23 & 5 & 0 \\
4 & 50 & 8 & 16 & 0 & 0 \\
Average & 33.25 & 34.75 & 27.75 & 5.50 & 1.75 \\
Std. Error & 7.52 & 11.43 & 10.99 & 3.01 & 1.44 \\
\hline
\end{tabular}

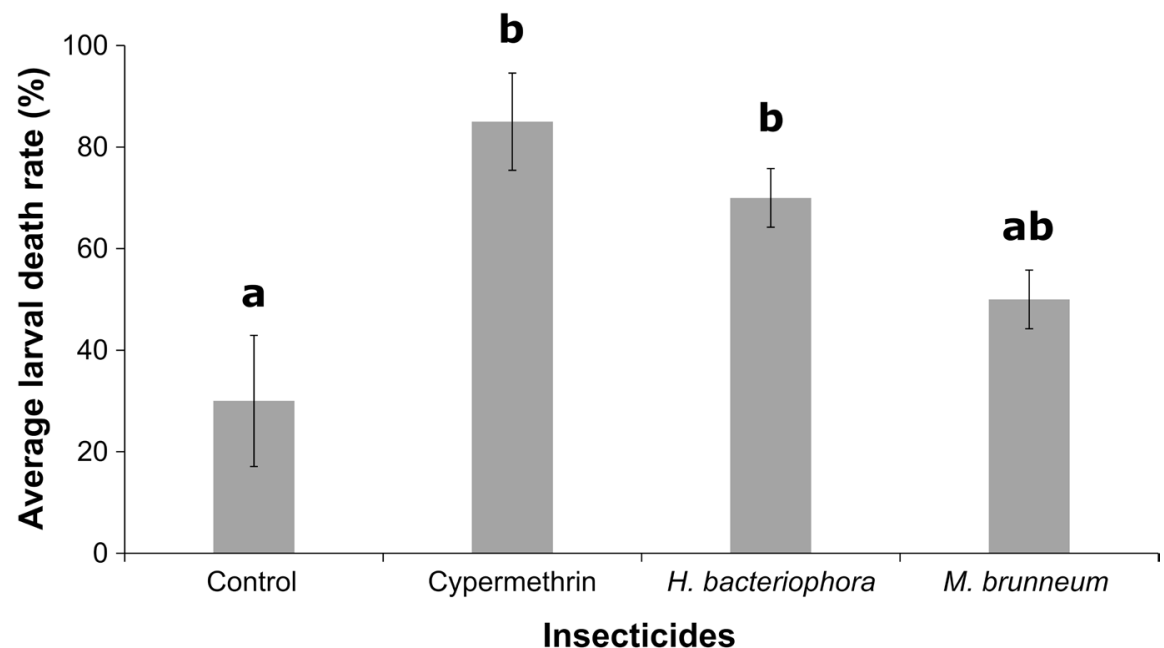


Table 2 Number of third instar larvae of Popillia japonica that survived the treatments out of an initial number of five

\begin{tabular}{lllll}
\hline Replicate & Control & Cypermethrin & $\begin{array}{l}\text { H. bacte- } \\
\text { riophora }\end{array}$ \\
\hline 1 & 4 & 2 & 1 & 3 \\
2 & 3 & 0 & 1 & 2 \\
3 & 2 & 0 & 2 & 3 \\
4 & 5 & 1 & 2 & 2 \\
Average & 3.50 & 0.75 & 1.50 & 2.50 \\
Std. Error & 0.65 & 0.48 & 0.29 & 0.29 \\
\hline
\end{tabular}

moved in several ways, including shipment of nursery stock infested with larvae (EFSA PLH Panel, 2018; National Plant Board, 2019). The risk of transporting $P$. japonica with plant material or products containing soil or potting substrate from infested areas is high, since females lay their eggs during the summer and the larvae remain in the soil until May or June of the following year (Fleming, 1972). Presence of larvae in balled and burlapped nursery stock, containergrown plants, or in grass sod can result in rejection of such commodities for national and international commerce.

The results obtained in this study showed that the weed mulching and the container substrate incorporated with insecticides are effective, practical strategies to avoid and control the $P$. japonica infestation in container-grown nursery stock. Although most studied treatments had statistically fewer larvae than the untreated control, from a regulatory perspective, none of them met alone the quarantine requirement of the absence of larvae in the containers. It should be considered, however, that the results are preliminary and more replicates under different experimental conditions are required to achieve general conclusions. However, the high effectiveness of the method could make it a suitable component of a systems approach strategy for pest risk management, in order to achieve a safe production and trade of nursery plant material in areas infested by the Japanese beetle (EPPO, 2021). In particular, the suggested methods need to be further tested in various combinations between them and with other control methods such as insect-proof netting.

In general, the experimental results can be discussed at three levels. First, it is generally acknowledged that natural infestations by the Japanese beetle in container plants are unlikely (Ladd \& Lawrence, 1986). Second, the container substrate was tested on third instar, which is the least susceptible to insecticides (Cowles et al., 1999; Dhadialla et al., 1998; Grewal et al., 2001; Mannion et al., 2001). Third, the adults were held in the containers in a no choice scenario, which likely concentrated the infestation potential. In a natural field setting where adult beetles have an oviposition choice, the tested control methods should be more effective and a suppression of the larvae in container-grown nursery stock is expected, especially if pest control methods are used in combination.

The coconut mulching provided good efficacy as an oviposition barrier. The thicker treatment reduced $95 \%$ of the total number of eggs laid in the container substrate compared with the control treatment. In two out of four containers, no larvae were present; in the other two containers, one and six larvae were found (Table 1). During the container inspections, some adult beetles were found under the fibre mulching and that was explained by to the presence of gaps between the mulch cover and the container. Gaps were occasionally observed and were explained with the expansion/contraction of the container with temperature and substrate hydration. It could be possible that gaps were formed at some time during the trial in all the containers and beetles could enter the substrate if they were ready for oviposition at that specific time. The correct positioning and maintenance of the mulching disks is therefore very important.

The only insecticide (cypermethrin) authorized in the European nursery industry for soil application on turf and ornamentals and the nematode $H$. bacteriophora provided significant reduction of larval numbers. Another biocontrol agent, the fungus M. brunneum, was less effective (Table 2). As M. brunneum is known to cause delayed mortality up to two months (Dhoj et al., 2008), it is likely that the time between the application and the check (14 days) was insufficient to allow the maximum expression of the fungus control potential.

In the U.S., the Domestic Japanese Beetle Harmonization Plan (DJHP) provides guidelines for accreditation of containerized nursery stock by cultural practices and by treatment (preplant media granule incorporation, dip, or drench application) of container-grown nursery stock shipped between Japanese beetle infested and non-infested states (National 
Plant Board, 2019). Immersion of containers in an insecticide solution can control larvae in nursery stock, but the procedure is difficult, potentially hazardous for operators and can be phytotoxic (Mannion et al., 2000). Drench applications provide an option for protecting plants growing in previously untreated substrate. While still labour intensive, a drench treatment requires less labour than dip procedures. Of all options, preplant granular incorporation into substrate of granular formulations seems to be the most labourefficient practice (Nielsen \& Cowles, 1998).

Good nursery and pest management practices dictate that growers do not rely on effective chemical treatments to be stand-alone tactics for control of $P$. japonica in container nursery production. A systems approach that combines different tactics (ISPM 14, 2002) seems to be the most promising way to control the Japanese beetle, especially when stand-alone methods are not effective or available. Other practices can minimize the risk of egg-laying by adults and should be adopted as part of an integrated management program. For example, Japanese beetles may only lay eggs in container nursery stock in which grasses, sedges or weeds are growing, or are immediately adjacent to grasses (Smitley, 1994). Maintaining containers as much as possible free of weeds, especially grasses, and isolating them from the soil is consequently important for reducing the risk of nursery plant infestation by larvae (National Plant Board, 2019). Turf adjacent to growing sites should be treated to control scarabeid larvae, thereby minimizing the flight of adults into container production areas (Potter \& Held, 2002). In addition, canopy applications of insecticides or repellents during the flight period can reduce the number of beetles in the production area.

The nursery industry needs effective treatments for $P$. japonica that are affordable, practical and minimize environmental risks. The absence of registered insecticides and the slow activity or lack of efficacy of alternative products against larvae, has left the nursery industry with few options for remedial control of $P$. japonica larvae. In this study, a new method based on mulching to limit the oviposition and the application of insecticides currently available in the European nursery industry is presented as a first step to the building of a systems approach that may allow a safe production and trade of nursery plant material from areas invaded by the Japanese beetle.
Acknowledgments The authors thank Dr. Andrea Pellegatta from Assofloro Lombardia for the logistic support, the technicians and the staff of Cooperativa della Comunità Soc. Coop. Sociale - ONLUS for Popillia japonica adult caging and larvae collection, the nursery manager Franco Vanoni for containers maintenance/rearing. Language was kindly revised by Mizuki Uemura.

Authors' contribution NM, GS and AB conceived and designed research. NM, GS, AB and IG conducted experiments. GS performed data analysis. MC, BC started the work and provided regulatory information on pest and insecticides. GG provided supervision. NM, GS, AB and IG wrote the manuscript. All authors read and approved the manuscript.

Funding This work was supported by Regione Lombardia - Direzione Generale Agricoltura through the Project GESPO (CUP: E86C18002720002) - New methodologies for the integrated management of Popillia japonica (2018-2022) within the framework "Bando per il finanziamento di progetti di ricerca in campo agricolo e forestale".

Data availability Raw data are accessible as: Battisti, Andrea (2021), "Management of Popillia japonica in container-grown nursery stock in Italy", Mendeley Data, V1, https://doi.org/10. 17632/hg925g4j6y.1

\section{Declarations}

Ethics approval The research meets ethical guidelines and adheres to the legal requirements of the study country. This research does not involve human subjects.

Consent to participate Not applicable

\section{Consent for publication Not applicable}

Conflict of interest The authors declare that they have no conflicts of interest.

Open Access This article is licensed under a Creative Commons Attribution 4.0 International License, which permits use, sharing, adaptation, distribution and reproduction in any medium or format, as long as you give appropriate credit to the original author(s) and the source, provide a link to the Creative Commons licence, and indicate if changes were made. The images or other third party material in this article are included in the article's Creative Commons licence, unless indicated otherwise in a credit line to the material. If material is not included in the article's Creative Commons licence and your intended use is not permitted by statutory regulation or exceeds the permitted use, you will need to obtain permission directly from the copyright holder. To view a copy of this licence, visit http://creativecommons.org/licenses/by/4.0/. 


\section{References}

Cowles, R. S., Alm, S. R., \& Villani, M. G. (1999). Selective toxicity of halofenozide to exotic white grubs (Coleoptera: Scarabaeidae). Journal of Economic Entomology, 92, 427-434. https://doi.org/10.1093/jee/92.2.427

Dhadialla, T. S., Carlson, G. R., \& Le, D. P. (1998). New insecticides with ecdysteroidal and juvenile hormone activity. Annual Review of Entomology, 43, 545-569. https://doi.org/10.1146/annurev.ento.43.1.545

Dhoj, Y., Keller, S., Nagel, P., \& Kafle, L. (2008). Virulence of Metarhizium anisopliae and Beauveria bassiana against common white grubs in Nepal. Formosan Entomology, 28, 11-20.

EFSA PLH Panel. (2018). Scientific opinion on the pest categorization of Popillia japonica. The EFSA Journal, 16, 5438. https://doi.org/10.2903/j.efsa.2018.5438.

EPPO. (2014). First report of Popillia japonica in Italy. EPPO Reporting Service, 10, 179. https://gd.eppo.int/reporting/ article-3272

EPPO. (2016). Diagnostics Popillia japonica, PM 7/74 (1). EPPO Bulletin, 36, 447-450.

EPPO. (2021). Popillia japonica. EPPO datasheets on pests recommended for regulation. Available online. https://gd. eppo.int

EU Pesticide Database. (2020). https://ec.europa.eu/food/plant/ pesticides/eu-pesticides-database/public/?event=homep age \&language $=\mathrm{EN}$

Fleming, W. E. (1972). Biology of the Japanese beetle. USDA Technical Bulletin 1449, 129 pp. https://naldc.nal.usda. gov/download/CAT87201410/PDF

Grewal, P. S., Power, K. T., \& Shetlar, D. J. (2001). Neonicotinoid insecticides alter diapause behavior and survival of overwintering white grubs (Coleoptera: Scarabaeidae). Pest Management Science, 57, 852-857. https://doi.org/ $10.1002 / \mathrm{ps} .373$

ISPM 14. (2002). The use of integrated measures in a systems approach for pest risk management. IPPC, FAO. http:// www.fao.org/3/a-y4221e.pdf

Ladd, T. L., \& Lawrence, K. O. (1986). Elimination of Japanese beetle larvae from plant growth medium by using isofenphos. Journal of Agricultural Entomology, 3, 170-174.

Mannion, C. M., McLane, W., Klein, M. G., Nielsen, D. G., \& Herms, D. A. (2000). Insecticide dips for control of Japanese beetle and other soil-infesting white grubs in B\&B nursery stock. Journal of Environmental Horticulture, 18, 89-93. https://doi.org/10.24266/0738-2898-18.2.89

Mannion, C. M., McLane, W., Klein, M. G., Moyseenko, J., Oliver, J. B., \& Cowan, D. (2001). Management of earlyinstar Japanese beetle (Coleoptera: Scarabaeidae) in fieldgrown nursery crops. Journal of Economic Entomology,
94, 1151-1161. https://doi.org/10.1603/0022-0493-94.5. 1151

Martins, A., \& Simoes, N. (1988). Suppression of the Japanese beetle in the Azores: an ecological approach. Ecological Bulletins, 39, 99-100.

National Plant Board. (2019). US Domestic Japanese Beetle Harmonization Plan. https://nationalplantboard.org/wpcontent/uploads/docs/jbhp_2017_update.pdf

Nielsen, D. G., \& Cowles, R. S. (1998). Preventing white grub infestation in container-grown nursery stock. Journal of Environmental Horticulture, 16, 202-207. https://doi.org/ 10.24266/0738-2898-16.4.202

Oliver, J. B., Reding, M. E., Ranger, C. M., Klein, M. G., Youssef, M. N., Moyseenko, J. J., \& Dennis, S. O. (2016). Insecticides evaluated as regulatory immersion treatments to eliminate third-instar Japanese beetles (Coleoptera: Scarabaeidae) from small-diameter field-grown nursery plants. Journal of Entomological Science, 51, 9-28. https://doi.org/10.18474/JES15-13.1

Oliver, J. B., Ranger, C., Reding, M., Youssef, N., \& Moyseenko, J. (2017). Insecticides and their combinations evaluated as regulatory immersion treatments for thirdinstar Japanese Beetle (Coleoptera: Scarabaeidae) in fieldgrown and containerized nursery plants. Journal of Entomological Science, 52, 274-287. https://doi.org/10.18474/ JES17-18.1

Pavesi, M. A. (2014). Popillia japonica specie aliena invasiva segnalata in Lombardia. L'Informatore Agrario, 32, 53-55.

Potter, D. W., \& Held, D. A. (2002). Biology and management of the Japanese beetle. Annual Review of Entomology, 47, 175-205. https://doi.org/10.1146/annurev.ento.47.091201. 145153

R Core Team. (2020). R: a language and environment for statistical computing.

Regione Lombardia. (2020). Popillia japonica information sheet. https://www.regione.lombardia.it/wps/portal/istit uzionale/HP/DettaglioRedazionale/servizi-e-informazio ni/Imprese/Imprese-agricole/servizio-fitosanitario-regio nale/organismi-nocivi/popillia-japonica/popillia-japonica

Smitley, D. R. (1994). Dealing with the Japanese beetle: a new approach. Nursery Business Grower, Aug 1994, 6-7.

Smitley, D. R. (1996). Incidence of Popillia japonica (Coleoptera: Scarabaeidae) and other scarab larvae in nursery fields. Journal of Economic Entomology, 89, 1262-1266. https://doi.org/10.1093/jee/89.5.1262

Publisher's note Springer Nature remains neutral with regard to jurisdictional claims in published maps and institutional affiliations. 